\title{
The Capacity of Idano Gana'a Village-Owned Enterprises in Increasing Community Participation in Dahana Tabaloho Village, Gunungsitoli District
}

\author{
Forester Kristin Putri Mendrofa ${ }^{1}$, R. Hamdani Harahap ${ }^{2}$, Tunggul Sihombing ${ }^{3}$ \\ ${ }^{1,2,3}$ Universitas Sumatera Utara, Indonesia \\ Corresponding Author: Forester Kristin Putri Mendrofa
}

\begin{abstract}
This study aims to determine the capacity of Idano Gana'a Village-Owned Enterprises (BUMDes) in increasing community participation in Dahana Tabaloho Village, Gunungsitoli District. BUMDes aims to improve the welfare of rural communities. The capacity of BUMDes in terms of human resources, capital and infrastructure can increase community participation so that the objectives of BUMDes can be achieved. The method used in this research is descriptive qualitative, by conducting observations, interviews, documentation and triangulation. The informants in this study included the Director of BUMDes, Treasurer of BUMDes, Head of BUMDes Business Unit, Village Head, Head of BPD, Camat, Head of Village Community Empowerment Service, Head of Trade and Industry Office, BUMDes Employees and Dahana Tabaloho Village Community. Data analysis techniques in this study are data reduction, data presentation, and drawing conclusions or verification. The results obtained in this study show that the capacity of BUMDes Idano Gana'a plays an important role in increasing community participation in Dahana Tabaloho Village. Human resources managing BUMDes operations, capital and infrastructure for BUMDes are able to increase community participation both in participating in decision making, implementing activities, monitoring and evaluating and utilizing development results.
\end{abstract}

Keywords: Capacity, Village-Owned Enterprises, Community Participation

\section{INTRODUCTION}

As a democracy with a population of more than 270 million people according to the 2020 population census data, Indonesia has great power to emerge as a 'global player'. This starts from the level of the country's ability to meet all domestic needs through local production, then being able to expand in the form of exports of original products made in Indonesia as part of the global trade chain. The ability to manage the state to reach all levels of society from the central level to the regional level is a form of state sovereignty. This is the goal that was sparked by the 'Founding Father' of Indonesia in formulating the basis of the state based on Pancasila.

Improving and guaranteeing the welfare of the people are the ideals and main objectives of the administration of the Indonesian government. The presence of the government as a regulator and operator of development, provides a way for the community to obtain services and develop all regional potentials so that they can be managed to improve community welfare.

The government's capacity to implement good governance plus the involvement of active community participation is the two main factors for achieving development goals. The achievement of development goals must of course pay attention to factors related to capacity development including shared commitment, conducive leadership, 
institutional reform, and increasing the strength possessed (Soeprapto, 2003:12).

According to Mubyarto in

(Fahrudin, 2014:37) participation is awareness to help the success of each program according to each person's ability without sacrificing one's own interests. Community participation is needed in achieving development goals. A government program will not achieve maximum results if the community does not participate in running the program.

Village development is part of a series of national development. National development is a series of sustainable development efforts that cover all aspects of people's lives. One of the missions of the Indonesian government under the command of President Jokowi in developing rural areas is to empower communities which will ultimately increase productivity and business diversity in rural areas. This is intended so that villages have the facilities and infrastructure to support their economic activities independently, build and strengthen existing institutions, support production and marketing chains, and optimize resources as the basis for rural economic growth.

According to Law Number 6 of 2014 concerning Villages, a village is a village and customary village or what is referred to by another name hereinafter referred to as a village is a legal community unit that has territorial boundaries that are authorized to regulate and manage government affairs, the interests of the local community based on community initiatives, rights of origin and/or traditional rights that are recognized and respected in the system of government of the unitary state of the Republic of Indonesia.

Villages in Indonesia have a major role in supporting national development. The welfare of rural communities is the basis of national development. A prosperous village is a reflection of a developed country. Villages are often even a support or supporter of urban areas. The city of Medan, for example, is supported by the surrounding areas as a total and continuous supplier of community needs. Fruits and various vegetables are supplied by Karo Regency, the availability of fish and seafood is supplied from the west coast, rice is supplied by Deli Serdang Regency, and even clean water is also supported by the surrounding area. This shows how the role of the village in supporting urban areas in a mutually beneficial system.

Rural development is important considering its very large role for the sustainability of urban communities in the simple to the national scope. This is because most of the Indonesian population are rural people who automatically become the face of Indonesia in the eyes of the world. One of the government's goals in implementing village development programs is to create independent, prosperous and sovereign village communities through village ministry programs in accordance with the potential that exists in the village.

One of the missions of the Government of Indonesia in developing rural areas is to empower communities which will ultimately increase productivity and business diversity in rural areas (Sofyani et al., 2019:46). One of the programs implemented by the government through the village ministry and local government is the distribution of village funds to all villages in Indonesia with a nominal amount adjusted to the population, village area, village potential and village community potential and the poverty level of a village.

Village funds are state funds sourced from the state revenue and expenditure budget (APBN) which are intended for traditional villages and villages to finance government administration, support village development, as well as for empowering community welfare and other community activities in accordance with Government Regulation Number 60 of 2014. The main priority in using the village fund must aim to provide the maximum benefit to the village community in the form of improving the quality of life, increasing welfare, 
reducing poverty, and improving public services. The village fund itself has begun to be distributed since 2015 in stages in accordance with the mandate of Law Number 06 of 2014 which provides legal protection for village-owned enterprises (BUMDes) as economic actors who manage the collective potential of the village to improve the welfare of the villagers.

In order to improve the welfare of rural communities, the central government through the Ministry of Villages gives full authority to villages to regulate village households and manage village finances sourced from village original income, APBN budget allocations, regional taxes and levies, allocation of village funds, financial assistance from regional revenue and expenditure budget (APBD) Province, and Regency APBD.

BUMDes are business entities whose capital is wholly or most of the capital owned by the village through direct participation originating from separated village assets in order to manage assets, services, and other businesses for the greatest welfare of the village community (Khanifah et al., 2019:6).

BUMDes aims to improve the welfare of rural communities. The capacity of BUMDes in terms of human resources, capital and infrastructure can increase community participation so that the objectives of BUMDes can be achieved.

BUMDes is a forum for advancing the rural economy in its role to improve the welfare of rural communities. The existence of BUMDes can become an icon in realizing village economic independence. Through the presence of BUMDes, it is expected to be able to stimulate and move the wheels of the village economy which is fully managed by the village community. Village communities can learn to grow the potential of the village into an activity that is both economic and useful as a social tool. Through business activities, BUMDes can also become a means of sustainable poverty alleviation in the village. The presence of BUMDes is also expected to fill the space as the fourth pillar of Indonesia's people's economy. The existing pillars of Indonesia's populist economy are SOEs, Cooperatives, MSMEs and their accessories. The presence of BUMDes is the fourth pillar to support the people's economy that continues to be developed in Indonesia (Wahid et al., 2019:318).

In North Sumatra, one of the developing BUMDes is BUMDes Sastro 316, Denai Lama Village, Pantai Labu District, Deli Serdang Regency. BUMDes Sastro 316 was established in 2016 and one of the programs of BUMDes Sastro 316 is managing the Paloh Naga tourist attraction with a wide and green expanse of rice fields that can refresh the eyes of visitors (Saragi and Abdullah, 2018). BUMDes Sastro has succeeded in improving the economy of the people of Denai Lama Village through the management of tourism objects so that the village community has additional income either as food or snack traders and provides lodging or homestays to visitors.

The establishment of BUMDes is not only in villages located in large provincial areas but also in villages located in small provinces far from metropolitan urban areas. One of the BUMDes that is the location of this research is Idano Gana'a BUMDes which is located in Dahana Tabaloho Village, Gunungsitoli District, Gunungsitoli City.

This study aims to determine the capacity of Idano Gana'a BUMDes in increasing community participation in Dahana Tabaloho Village, Gunungsitoli District.

\section{RESEARCH METHODS}

The method used in this research is descriptive qualitative, by conducting observations, interviews, documentation and triangulation. Qualitative research is research that intends to understand phenomena about what is experienced by research subjects such as behavior, perceptions, motivations, actions, etc., holistically and by means of descriptions in the form of words and language, in a special 
context that is natural and with utilizing various natural methods (Moleong, 2016:6). Descriptive research is a type of research that aims to make a systematic, factual and accurate description of the facts and characteristics of the population of a particular area (Pandiangan, 2015).

The research was conducted at Idano Gana'a Village-Owned Enterprises (BUMDes) in Dahana Tabaloho Village, Gunungsitoli District. The reason the author chose this location is that Idano Gana'a BUMDes is still far behind and needs an even harder struggle to match and even exceed the success of successful BUMDes such as Ponggok Tirta Mandiri BUMDes. Ponggok Tirta Mandiri BUMDes is located in Polanharjo District, Klaten Regency, Central Java.

The sources of data in this study are the words and actions of the informants as primary data and written data or documents that support the informants' statements. Library research of reference sources is a form of research that uses library facilities by examining theoretical discussions from various books, articles, and scientific works related to writing (Pandiangan, 2018).

Research informants or someone who provides information related to the research title are those who are directly or indirectly involved in the role of Idano Gana'a BUMDes towards improving the welfare of the community in Dahana Tabaloho Village, and they are expected to be able to convey information about the actual conditions happens in the field. The informant selection technique in this study used a purposive sampling procedure. According Pandiangan et al. (2018) in Sugiyono, purposive sampling is the selection of samples based on certain characteristics that are considered to have relevance to the characteristics of the population that have been known previously. The informants in this study included the Director of BUMDes, Treasurer of BUMDes, Head of BUMDes Business Unit, Village Head, Head of BPD, Camat, Head of Village Community
Empowerment Service, Head of Trade and Industry Office, BUMDes Employees and Dahana Tabaloho Village Community.

After the continuation of the data collection activities that have been obtained are then analyzed using qualitative methods. The analysis is used to understand the relationships and concepts in the data so that they can be developed and evaluated. Based on the foregoing, it can be stated that data analysis is the process of systematically searching and compiling data obtained from observations, interviews and documentation so that they can be understood easily and make conclusions with the aim of being able to inform and be easily understood by people. Data analysis techniques in this study are data reduction, data presentation, and drawing conclusions or verification. Data obtained from the field requires special treatment in order to obtain data that is in accordance with predetermined standards. For this reason, the data obtained need to be recorded, sorted, presented individually and only then can conclusions be drawn from the data obtained through observation, interviews, and documentation (Tobing et al., 2018).

\section{RESULT}

\section{Dahana Tabaloho Village, Gunungsitoli District Overview}

Dahana Tabaloho Village is one of the villages in the Gunungsitoli sub-district which has an area of about $2.90 \mathrm{~km} 2$ and is the village with the 13th largest area of the 32 villages and sub-districts in the Gunungsitoli District. There are two hamlets in the Dahana Tabaloho Village area, namely Hamlet I and Hamlet II.

The data obtained by the author regarding the population of Dahana Tabaloho Village there are 1571 inhabitants consisting of 800 men and 771 women with a total of 376 families. It can be seen from the population data that the male population is more than the female population.

Economic conditions are closely related to people's sources of livelihood. Everyone always tries to get a job according 
to their respective fields and expertise. In general, it can be explained that the residents of Dahana Tabaloho Village make a living as farmers, besides farmers there are also those who work as traders, laborers, private employees, civil servants and so on.

The people of Dahana Tabaloho Village are mostly inhabited by the Nias tribe. In addition to the Nias tribe, there are also various other tribes that came as a result of inter-tribal marriages such as the Toba Batak, Karo, Javanese, and Chinese. Gotong royong is also highly respected by the community in everyday life, whether it is in traditional ceremonies such as marriage customs, death, inauguration of a new house by donating materials and labor. The very close kinship system makes the people of Dahana Tabaloho Village very tolerant of each other. This is proven by attending traditional ceremonies, visiting sick people, and others which they consider as something that must be done so that life between communities is mutually sustainable.

Administratively, the administration of Dahana Tabaloho Village, Gunungsitoli District, is under the working area of Gunungsitoli District, Gunungsitoli City. Dahana Tabaloho Village is part of the Gunungsitoli District, Gunungsitoli City which is led by a Village Head and in carrying out its duties is assisted by staff consisting of the Village Secretary, Section Head (Kasi), Head of Kaur Affairs, Hamlet Head (Kadus) and Village Consultative Body (BPD).

\section{Idano Gana'a Village-Owned Enterprises (BUMDes)}

Idano Gana'a Village-Owned Enterprises (BUMDes), Dahana Tabaloho Village, Gunungsitoli District, Gunungsitoli City was established on October 14, 2019 through Village Regulation Number 18 of 2019 concerning the establishment of Idano Gana'a BUMDes. Idano Gana'a BUMDes manages 5 (five) types of businesses, namely: banana, cassava and taro chips management business, durian coffee management business, milk ginger management business, coffee shop business and culinary business.

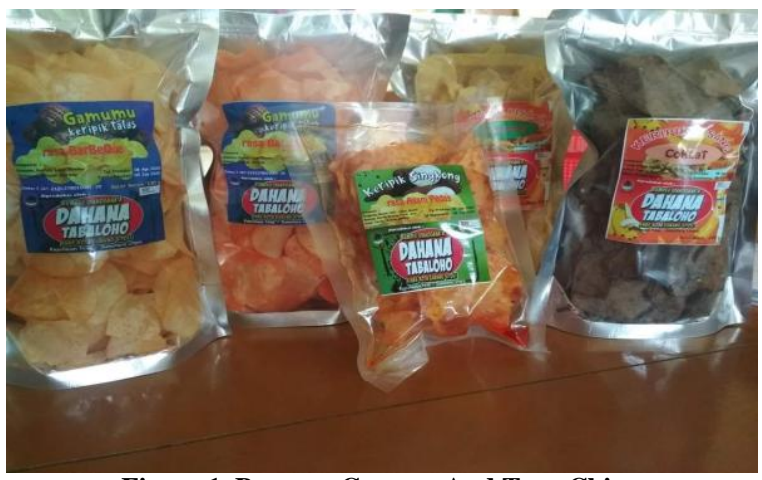

Figure 1. Banana, Cassava And Taro Chips

Source: Idano Gana'a BUMDes Documentation

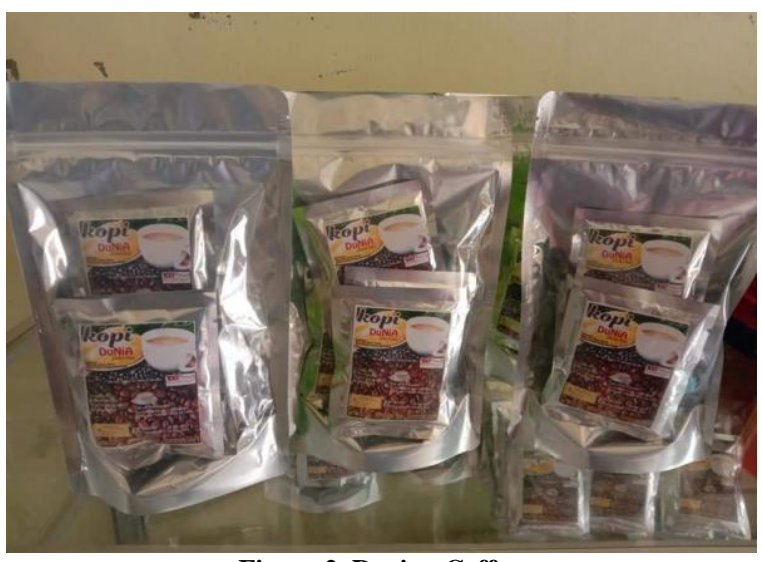

Figure 2. Durian Coffee

Source: Idano Gana'a BUMDes Documentation

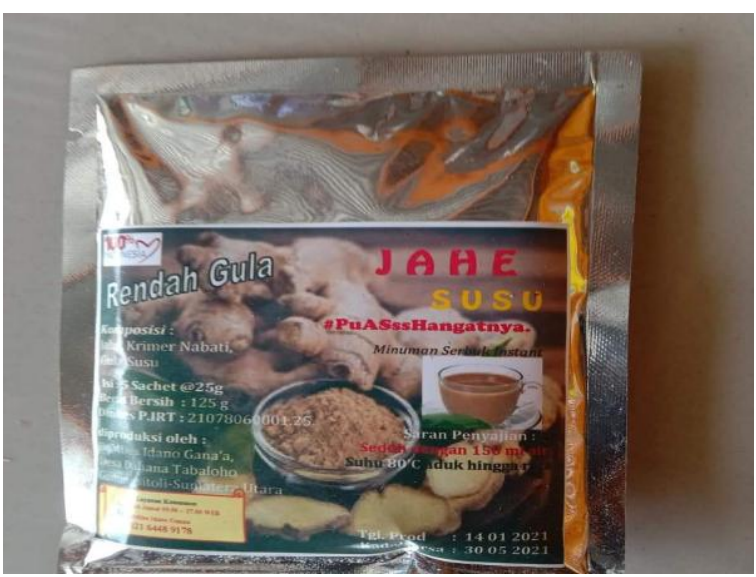

Figure 3. Milk Ginger

Source: Idano Gana'a BUMDes Documentation

Following up on Gunungsitoli Mayor's Regulation Number 65 of 2017 concerning procedures for establishing, managing and managing and dissolving BUMDes, the village head of Dahana Tabaloho took steps related to the establishment of BUMDes. The first step 
taken by the village government is to disseminate information about BUMDes. In this initial stage, the villagers who were holding the deliberations at that time agreed to establish a BUMDes.

In line with the Village Head's statement regarding the establishment of BUMDes, the chairman of the BPD and one of the community members also conveyed the same thing, that the people of Dahana Tabaloho Village approved the establishment of BUMDes, considering the benefits and importance of establishing BUMDes to improve the economy of the Dahana Tabaloho Village community.

In line with the statement from the Head of Dahana Tabaloho Village, the Head of the Gunungsitoli City Trade and Industry Office confirmed that the Dahana Tabaloho Village Head requested that special training be given to find out which products could be processed by Dahana Tabaloho Village into a BUMDes business unit to be established.

In accordance with the statement by the head of the Gunungsitoli City Trade and Industry Office, that at first he doubted the intention of Dahana Tabaloho Village to request special training, in fact it was not without clear reasons. This is the effect of the many BUMDes that have been established and have held trainings but in the end there are no results that show the success of a business unit. However, in this case, Dahana Tabaloho Village provides an example that they are really committed to establishing the BUMDes.

The results obtained in this study show that the capacity of Idano Gana'a BUMDes plays an important role in increasing community participation in Dahana Tabaloho Village. Human resources managing BUMDes operations, capital and infrastructure for BUMDes are able to increase community participation both in participating in decision making, implementing activities, monitoring and evaluating and utilizing development results.

\section{Idano Gana'a BUMDes Capacity in Terms of Human Resources Dimensions \\ Idano Gana'a BUMDes human} resource capacity building is carried out starting from the individual, group and organizational levels. The increase in human resource capacity is carried out, among others, through education and training related to improving the ability to manage the organization, starting from the basics of the organization to the division of labor for each unit in the BUMDes.

Human resources marked as workers, personnel or employees are a set of organizational units in carrying out a job whose division of labor is regulated and made based on the ability and suitability of educational background and experience. The resources in Idano Gana'a BUMDes are a group of people, part of an organization or operational executor who occupies a position in the organization and works according to the abilities and job descriptions that have been prepared previously.

Human resources as an organizational driver means that the people involved in an organization are a unified whole to run the wheels of the organization starting from the planning stage, program implementation to overall evaluation which is expected to be able to keep the pace of the organization on the axis that has been mutually agreed upon. In this case, every individual who exists and is directly involved in Idano Gana'a BUMDes is the driving force of the BUMDes organization in each of its business units which is directly responsible for the continuity of Idano Gana'a BUMDes. The human resources referred to are BUMDes operational managers starting from the Director, Treasurer and Head of Business Unit. The capacity of BUMDes operational managers in managing BUMDes is an illustration of the capacity of BUMDes itself.

The capacity of human resources who are the operational managers of Idano Gana'a BUMDes is generally quite good. The Director of Idano Gana'a BUMDes is a 
master of management graduate with considerable work experience in the organizational world.

In line with what was conveyed by the Head of Dahana Tabaloho Village, the Head of the Gunungsitoli Sub-district and the Head of the Gunungsitoli City PMD/K Service also said that the Director of Idano Gana'a BUMDes was quite experienced in the business world and also had an educational background, namely a management master whose discipline was very beneficial for the community. Organizational continuity both from leadership and also the innovations made to develop BUMDes.

The process of selecting the BUMDes treasurer is carried out by direct appointment to the individual concerned for mutual approval in village deliberation meetings. The treasurer of Idano Gana'a BUMDes is currently a housewife who graduated from high school/equivalent. Even though with an educational background that does not support positions in the BUMdes structure, it is based on a willingness to learn and accept responsibility as initial capital to become a BUMDes treasurer.

Dahana Village itself does not have many candidates who are willing to fill the position as BUMDes treasurer because there are no incentives or fixed salaries given to the management. The provision of incentives to advisors, supervisors and operational implementers of BUMDes is given if the BUMDes has produced, in other words, salaries/incentives/honors can only be taken from the results of BUMDes operations and not from initial capital or village capital participation.

\section{Idano Gana'a BUMDes Capacity in Terms of Money/Capital Resources Dimensions}

The financial dimension is the budget allocation in carrying out the functions and achieving organizational goals. An organization will find it difficult to realize the plan that will be carried out if it is constrained by financial problems or often referred to as capital.

The initial capital of Idano Gana'a BUMDes comes from village capital participation. In 2019, the capital investment given to BUMDes was Rp151,000,000 (one hundred and fifty one million rupiah) and in 2020 it was Rp223,000,000 (two hundred and twenty three million rupiah). This initial capital is used more for inventory posts and building rentals as BUMDes offices. For 2020 itself, BUMDes Idano Gana'a provides PAD to Dahana Tabaloho village of Rp5,000,000 which comes from profits from operations and the operational manager of BUMDes receives an honorarium of $\mathrm{Rp} 1,000,000$ per person.

As stated by the Dahana Village Head, BPD Chair and BUMDes Director Idano Gana'a above that BUMDes Idano Gana'a's capital only comes from equity participation from village funds. BUMDes equity participation in 2019 and 2020 is considered sufficient to drive the wheels of organization and production in each BUMDes business unit so that for 2021 BUMDes will not apply for additional capital.

The statement by the director and treasurer of Idano Gana'a BUMDes regarding 2021 not submitting a request for village capital participation was justified by the Village Head Dahana Tabaloho on the grounds that the existing capital is sufficient for the implementation of BUMDes operations and the management is trying to use the existing capital to increase BUMDes income. The management assumes that the increase in capital if it is not accompanied by an increase in business units that can certainly produce during the current pandemic will be ineffective and inefficient. Uncertainty in the economic situation during the COVID-19 andemic period as it is now forced to shift ande businesses engaged in the economy, especially small businesses, both individuals and organizations such as BUMDes. The Idano Gana'a BUMDes is currently thinking about 
business developments that will not be disrupted by the COVID-19 andemic.

\section{Idano Gana'a BUMDes Capacity in Terms of Infrastructure Dimensions}

Facilities and infrastructure are two types which are commonly referred to as facilities in an institution/organization. Idano Gana'a BUMDes facilities and infrastructure are existing facilities to support the management of all business units and activities in Idano Gana'a BUMDes. Facilities in the management of BUMDes are all equipment, materials and furniture that are directly used in the process of managing BUMDes. Some examples of the facilities of a BUMDes are tables and chairs in the BUMDes coffee shop (warkop), gas stoves, frying pans and other tools for the production of chips, as well as storage devices for raw materials such as refrigerators and so on.

Infrastructure in the management of BUMDes is all basic equipment that indirectly supports the implementation of the production process. One example of infrastructure in BUMDes management is the BUMDes building/office and office yard. Until now, the infrastructure owned by BUMDes Idano Gana'a is sufficient to support the management of business units so that they can continue to run and produce.

As stated by the informant above, it can be seen that the existing facilities and infrastructure at Idano Gana'a BUMDes have so far been sufficient. Infrastructure facilities are sourced from the BUMDes own capital and also assistance from the local government.

\section{Idano Gana'a BUMDes Capacity in Terms of Society Participation Dimensions}

Social strengthening or community participation can be done by providing the widest opportunity for village communities to participate in the operation and development of BUMDes.

According to Law Number 6 of 2014 concerning Villages Chapter X Article 87 paragraph 2 it is stated that BUMDes is managed in a spirit of kinship and mutual cooperation. In his explanation, it was stated that BUMDes was formed to utilize economic potential, economic institutions, natural resource potential and human resources in order to improve the welfare of rural communities. To realize the mandate of the law, it is necessary to have the participation of every member of the community to support the achievement of the objectives of establishing BUMDes.

\section{CONCLUSION AND SUGGESTION}

The results obtained in this study show that the capacity of BUMDes Idano Gana'a plays an important role in increasing community participation in Dahana Tabaloho Village. Human resources managing BUMDes operations, capital and infrastructure for BUMDes are able to increase community participation both in participating in decision making, implementing activities, monitoring and evaluating and utilizing development results.

The suggestions in this research are:

\section{Manager Idano Gana'a BUMDes}

The importance of human resource capacity in the success of an organization encourages each BUMDes management to further increase the capacity of themselves and the organization so that they can create better innovations in the future for the progress and sustainability of BUMDes in every existing business unit. The current potential is quite good, but there are still many things that need to be improved, one of which is to mobilize community participation so that they want to be more actively involved in the management of BUMDes and not just become consumers.

\section{Dahana Tabaloho Village Government, BPD and Supervisors}

The role of the village government in efforts to increase the capacity of an organization is very important. It is hoped that village government support for BUMDes will be further enhanced, and 

community participation in Dahana Tabaloho Village, Gunungsitoli district.

provide firmer solutions to problems/challenges faced by BUMDes. Likewise, BPD and supervisors as BUMDes work partners, in order to provide inputs that can increase the capacity of BUMDes, and help socialize and motivate the community to participate more actively.

\section{Dahana Tabaloho Village Community}

The progress of BUMDes is one of the efforts to improve village welfare and increase the economic rate of a village. It is hoped that the people of Dahana Tabaloho Village will participate more actively in building BUMDes and not just become consumers or customers. Community participation to provide suggestions and criticism directly at forums and deliberations carried out by the village government greatly helps BUMDes to be able to understand the needs of the community so that administrators, village governments and the community can jointly build villages through advanced and competitive BUMDes.

\section{Gunungsitoli City Government}

In times of pandemic like today, marked by a sluggish economy, it has a huge impact on business units run by the community and also BUMDes. The Gunungsitoli City Government is expected to be able to take the right policies to continue to pay attention to the sustainability of the BUMDes business. Assistance from the city government through the relevant agencies that handle BUMDes is very much needed, both material assistance and also assistance in strengthening the competence of BUMDes.

Acknowledgement: None

Conflict of Interest: None

Source of Funding: None

\section{REFERENCES}

1. Fahrudin, A. (2014). Pemberdayaan Partisipasi dan Penguatan Kapasitas Masyarakat. Bandung: Humaniora.

2. Khanifah, L. N., Sihidi, I. T., \& Hadi, K. (2019). Collaborative Governance to Increase Building Index in Economics Through Village-Owned Enterprises Sub District Ngroto, Malang. Advances in Social Science, Education and Humanities Research, 436, 854-857.

3. Moleong, L. J. (2016). Metodologi Penelitian Kualitatif. Bandung: Remaja Rosdakarya.

4. Pandiangan, Saut Maruli Tua. (2015). Analisis Lama Mencari Kerja Bagi Tenaga Kerja Terdidik di Kota Medan. Skripsi. Medan: Fakultas Ekonomi dan Bisnis, Program Studi Ekonomi Pembangunan, Universitas Sumatera Utara. https://www.academia.edu/52494724/Analis is_Lama_Mencari_Kerja_Bagi_Tenaga_Ker ja_Terdidik_di_Kota_Medan.

5. Pandiangan, Saut Maruli Tua. (2018). Analisis Faktor-faktor yang Mempengaruhi Penawaran Tenaga Kerja Lanjut Usia di Kota Medan. Tesis. Medan: Fakultas Ekonomi dan Bisnis, Program Studi Ilmu Ekonomi, Universitas Sumatera Utara. http://repositori.usu.ac.id/bitstream/handle/1 23456789/10033/167018013.pdf?sequence= 1\&isAllowed=y.

6. Pandiangan, Saut Maruli Tua, Rujiman, Rahmanta, Tanjung, Indra I., Darus, Muhammad Dhio, \& Ismawan, Agus. (2018). An Analysis on the Factors which Influence Offering the Elderly as Workers in Medan. IOSR Journal of Humanities and Social Science (IOSR-JHSS), 23(10), 76-79. DOI: $\quad 10.9790 / 0837-2310087679$. http://www.iosrjournals.org/iosrjhss/papers/Vol.\%2023\%20Issue10/Version -8/K2310087679.pdf.

7. Saragi, Nurmaulida., \& Abdullah (2018). Peran Badan Usaha Milik Desa Dalam Pengelolaan Objek Wisata Di Desa Denai Lama Kecamatan Pantai Labu Kabutapen Deli Serdang. Jurnal Pemberdayaan Masyarakat, 6, 2355-8679.

8. Soeprapto, H. R. (2003). Pengembangan Kapasitas Pemerintah Daerah Menuju Good. Pidato Pengukuhan Guru Besar dalam Ilmu Administrasi Pembangunan pada Fakultas Ilmu Administrasi Universitas Brawijaya. 
Forester Kristin Putri Mendrofa et.al. The capacity of Idano Gana'a village-owned enterprises in increasing community participation in Dahana Tabaloho Village, Gunungsitoli district.

9. Sofyani, H., Atmaja, R., \& Rezki, S. B. (2019). Success Factors of Village-Owned Enterprises (BUMDes) Performance in Indonesia: An Exploratory Study. Journal of Accounting and Investment, 20, 44-58. DOI: 10.18196/jai.2002116.

10. Tobing, Murniati, Afifuddin, Sya'ad, Rahmanta, Huber, Sandra Rouli, Pandiangan, Saut Maruli Tua, \& Muda, Iskandar. (2018). An Analysis on the Factors Which Influence the Earnings of Micro and Small Business: Case at Blacksmith Metal Industry. Academic Journal of Economic Studies, 5(1), 17-23. https://www.ceeol.com/search/articledetail $? \mathrm{id}=754945$.
11. Wahid, M. A., Nurhaeni, I. D., Sudarmo, \& Suharto, D. G. (2019). The Synergy Among Stakeholders in Management of VillageOwned Enterprises (BUM Desa). Advances in Social Science, Education and Humanities Research, 436, 317-320.

How to cite this article: Mendrofa FKP, R. Hamdani Harahap, Sihombing T. The capacity of Idano Gana'a village-owned enterprises in increasing community participation in Dahana Tabaloho Village, Gunungsitoli district. International Journal of Research and Review. 2021; 8(10): 289-298. DOI: https://doi.org/10. 52403/ijrr.20211039 